\begin{tabular}{l|l|l|} 
JURNAL MEGA AKTIVA \\
$\begin{array}{r}\text { Email : megaaktiva@febi.umkendari.ac.id } \\
\text { Website : } \text { https://megaaktiva.umkendari.ac.id/index.php/Jurnal }\end{array}$ \\
\hline
\end{tabular}

\title{
ANALISIS NILAI TAMBAH INDUSTRI TERHADAP PERTUMBUHAN EKONOMI (PDRB) DI PROVINSI SULAWESI TENGGARA
}

\author{
${ }^{1}$ Indri Hapsari \\ ${ }^{1}$ Fakultas Ekonomi dan Bisnis Islam, Universitas Muhammadiyah Kendari
}

\begin{abstract}
Penelitian ini bertujuan jangka panjang untuk menganalisis adanya pengaruh nilai tambah industri terhadap pertumbuhan ekonomi di Provinsi Sulawesi Tenggara Metode penelitian ini menggunakan data sekunder berupa literature maupun dokumentasi dengan responden instansi terkait pada kantor BPS Provinsi Sulawesi Tenggara dan data sekunder berupa data runtun waktu (time series) mengenai nilai tambah industri dan pertumbuhan ekonomi (PDRB) dengan menggunakan analisis regresi linier sederhana dengan metode Ordinary Least Square (OLS). Pengujian menggunakan uji t-statistik dengan menggunakan software program SPSS 16. Hasil penelitian ini menunjukkan Nilai Tambah Industri berpengaruh negatif hal ini menunjukkan belum mampu meningkatkan PDRB di provinsi Sulawesi Tenggara.
\end{abstract}

Kata kunci : Nilai Tambah Industri, Pertumbuhan Ekonomi (PDRB)

\section{PENDAHULUAN}

Indikator perkembangan pertumbuhan ekonomi di Provinsi Sulawesi Tenggara dapat dilihat dari nilai tambah industri besar/sedang termasuk sektor industri manufaktur di Sulawesi Tenggara perlu menjadi perhatian mengingat potensi sumber daya alam masih banyak yang belum optimal dimanfaatkan bagi kesejahteraan masyarakat di Sulawesi Tenggara. Tipe industri yang dimiliki oleh daerah Sulawesi Tenggara tergolong industri ekstraktif merupakan industri yang bahan bakunya diperoleh langsung dari alam seperti industri hasil pertanian, industri hasil perikanan, industri hasil kehutanan sehingga memiliki potensi yang besar untuk lebih meningkatkan peran dan mengembangkan sektor industri. Peranan ekspor dalam kegiatan ekonomi merupakan komponen utama dalam memacu pertumbuhan ekonomi (PDRB). Secara geografi Sulawesi Tenggara yang terdiri dari wilayah daratan dan kepulauan memiliki posisi strategis dan merupakan lahan yang cocok untuk perdagangan, apalagi ditunjang dengan daerah kemaritiman atau perairan laut yang luas memiliki akses melakukan transaksi perdagangan internasional. Tentunya Pemerintah di Provinsi Sulawesi Tenggara sebagai pihak yang berotoritas dapat mengembangkan arah kebijakan dalam pembangunan industrialisasi sebagai peningkatan nilai tambah Sedangkan untuk perkembangan Nilai Tambah Industri, tahun 2010-2016 dapat ditujukkan pada Tabel dibawah ini menunjukkan bahwa PDRB menunjukkan peningkatan dari tahun 2010 senilai Rp. 48.401.152,- sampai pada tahun 2016 senilai Rp. 77. 739.546,- 
Email : megaaktiva@febi.umkendari.ac.id

Website : https://megaaktiva.umkendari.ac.id/index.php/Jurnal

Tabel 1. Nilai Tambah Industri Terhadap PDRB di Provinsi Sulawesi Tenggara Tahun 2010-2016

\begin{tabular}{ccc}
\hline Tahun & Nilai Tambah (Ribuan Rp) & PDRB (Juta Rp) \\
\hline 2010 & 1.116 .747 .393 & 48.401 .152 \\
\hline 2011 & 3.508 .042 .274 & 53.546 .690 \\
\hline 2012 & 2.291 .799 .116 & 59.785 .399 \\
\hline 2013 & 2.605 .882 .900 & 64.268 .714 \\
\hline 2014 & 1.320 .715 .327 & 68.291 .785 \\
\hline 2015 & 2.566 .854 .111 & 72.991 .328 \\
\hline 2016 & 3.028 .887 .851 & 77.739 .546 \\
\hline
\end{tabular}

Dari gambar 1 ini memberikan suatu penjelasan bahwa nilai tambah industri pada tahun 2011 senilai Rp. 3.508.042.274,- dan 2016 terjadi peningkatan Rp. 3.028.887.851,, sehingga berdampak juga pada peningkatan PDRB.. Pertumbuhan ekonomi Sulawesi Tenggara dari tahun ke tahun menunjukkan peningkatan dan perlambatan pada suatu waktu. Pada tahun 2013 mencapai 7,50 persen. Namun pada tahun 2014 mengalami perlambatan dengan pertumbuhan 6,26 persen dan kemudian meningkat 6,88 persen tahun 2015. Pada tahun 2016 juga mengalami perlambatan yang hanya mencapai 6,51 persen yang tercatat pada gambar 1.

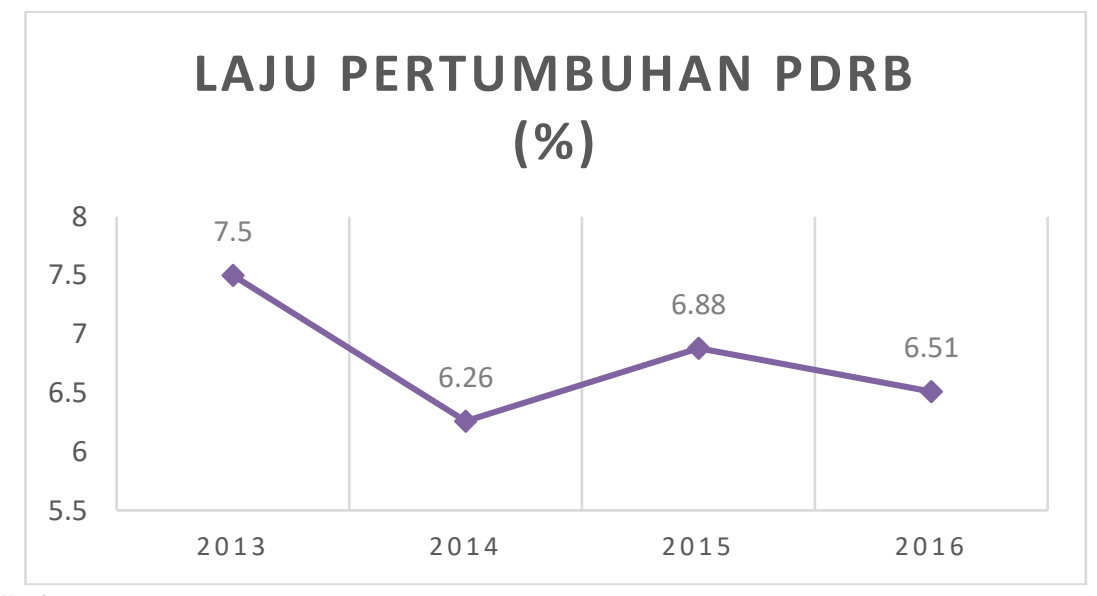

Sumber : BPS Sultra

\section{Gambar 1}

\section{Laju Pertumbuhan Produk Domestik Regional Bruto Atas Dasar Konstan 2010 Di} Provinsi Sulawesi Tenggara Persen, 2013 - 2016

Hal ini menunjukkan laju pertumbuhan PDRB atas dasar konstan 2010 Di Provinsi Sulawesi Tenggara pada tahun 2013 - 2016 tercatat perubahan yang mengalami peningkatan maupun penurunan. dapat dianalisis terhadap peningkatan atau penurunan pertumbuhan ekonomi ( PDRB). 
Email : megaaktiva@febi.umkendari.ac.id

Website : https://megaaktiva.umkendari.ac.id/index.php/Jurnal

\section{KAJIAN TEORITIS}

\section{Pertumbuhan ekonomi (PDRB)}

Secara umum, pertumbuhan ekonomi (PDRB) didefenisikan sebagai peningkatan kemampuan dari suatu perekonomian dalam memproduksi barang-barang dan jasa-jasa. Pertumbuhan ekonomi (PDRB) adalah salah satu indikator yang amat penting dalam melakukan analisis tentang pembangunan ekonomi yang terjadi pada suatu negara. Istilah pembangunan ekonomi biasanya dikaitkan dengan perkembangan ekonomi di negaranegara berkembang. Dengan perkataan lain, dalam mengartikan istilah pembangunan ekonomi, ahli ekonomi bukan saja tertarik kepada masalah perkembangan pendapatan nasional riil, tetapi juga kepada modernisasi kegiatan ekonomi, misalnya kepada usaha merombak sektor pertanian yang tradisional, masalah mempercepat pertumbuhan ekonomi (PDRB) dan masalah perataan pembagian pendapatan (Sukirno, 2006:423)

\section{Nilai Tambah Industri (besar/sedang)}

Perusahaan atau Usaha Industri didefinisikan sebagai unit (kesatuan) usaha yang melakukan kegiatan ekonomi, bertujuan menghasilkan barang dan jasa, terletak pada suatu bangunan atau lokasi tertentu, dan mempunyai catatan adaministrasi tersendiri mengenai produksi dan struktur biaya serta ada seorang atau lebih yang bertanggung jawab atas usaha tersebut. Industri pengolahan didefinisikan sebagai suatu kegiatan ekonomi yang melakukan kegiatan mengubah suatu bahan dasar secara mekanis,kimia atau dengan tangan sehingga menjadi barang jadi atau setengah jadi,dan/atau dari barang yang kurang nilainya menjadi barang yang lebih tinggi nilainya, dan sifatnya lebih dekat kepada pemakai terakhir.termasuk dalam kegiatan jasa indutri pekerjaan perakitan (assembling). Perusahaan industri pengolahan dibagi dalam 4 (empat) golongan yang hanya didasarkan kepada banyaknya tenaga kerja yang bekerja di perusahaan industri tersebut, tanpa memperhatikan apakah perusahaan tersebut menggunakan mesin tenaga atau tidak serta tanpa memperhatikan besarnya modal perusahaan.

Tabel 2. Golongan Industri Berdasarkan Jumlah Tenaga Kerja Di Provinsi Sulawesi Tenggara

Sumber : BPS Sultra

\begin{tabular}{cc}
\hline Golongan Industri & Banyaknya Tenaga Kerja \\
\hline Besar & 100 orang atau lebih \\
\hline Sedang & Antara 20-99 Orang \\
\hline Kecil & Antara 5-19 orang \\
\hline Mikro & Antara 1-4 orang \\
\hline
\end{tabular}

Jasa Industri didefinisikan sebagai kegiatan industri yang melayani keperluan pihak lain. Pada kegiatan ini bahan baku disediakan oleh pihak lain, sedangkan pihak pengolah hanya melakukan pengolahannya dengan mendapat imbalan sejumlah uang atau barang sebagai balas jasa. Misalnya perusahaan penggilingan padi yang melakukan kegiatan menggiling padi/gabah petani dengan balas jasa yang diperhitungkan secara bagi hasil.

Input atau biaya antara didefinisikan sebagai biaya yang dikeluarkan dalam proses industri yang berupa bahan baku, bahan bakar, barang lainnyadi luar bahan baku/bahan 
penolong,,jasa industri, sewa gedung dan biaya jasa non industri.Output didefinisikan sebagai nilai keluaran yang dihasilkan dari proses kegiatan industri yang berupa barang yang dihasilkan,tenaga listrik yang dijual, jasa industri,keuntungan jual beli, pertambahan stok barang setengah jadi dan penerimaan. Nilai Tambah atau Value Added di definisikan sebagai besarnya output dikurangi besarnya nilai input (antara) atau definisi nilai tambah adalah perbedaan antara nilai dari output suatu perusahaan atau suatu industri, yaitu total pendapatan yang diterima dari penjualan output tersebut, dan biaya masukan dari bahanbahan mentah, komponen-komponen atau jasa-jasa yang dibeli untuk memproduksi komponen tersebut. Nilai tambah adalah nilai yang ditambahkan oleh suatu perusahaan ke bahan-bahan dan jasa-jasa yang dibelinya melalui produksi dan usaha-usaha pemasarannya. Nilai tambah diketahui dengan melihat selisih antara nilai output dengan nilai input suatu industri. (BPS Sultra)

\section{METODE PENELITIAN}

Penelitian ini dilakukan di Provinsi Sulawesi Tenggara pada Kantor BPS Sultra mengenai analisis perkembangan nilai tambah indutri terhadap pertumbuhan ekonomi (PDRB). Metode analisis data yang digunakan dalam penelitian ini adalah metode pangkat kuadrat terkecil biasa atau Ordinary Least Square (OLS). Inti metode Ordinary Least Square (OLS) adalah mengestimasi suatu garis regresi dengan jalan meminimalkan jumlah dari kuadrat kesalahan setiap observasi terhadap garis tersebut (Kuncoro, 2007: 79). Analisis data yang dilakukan dalam penelitian ini akan menggunakan persamaan regresi dengan menggunakan metode regresi kuadrat terkecil atau Ordinary Least Square (OLS) dengan formulasi sebagai berikut :

$$
\mathrm{Y}=\beta 0+\beta 1 \mathrm{X} 1+e
$$

\section{HASIL DAN PEMBAHASAN}

\section{Perkembangan Jumlah Perusahaan (Industri)}

Perusahaan industri besar dan sedang di Sulawesi Tenggara dalam kurun waktu lima tahun terakhir (2011-2015), jumlah tercatat berfluktuasi seiring adanya perusahaan yang tutup sementara, tutup permanen, berubah klasifikasi menjadi industri kecil, atau terdapat perusahaan baru yang mulai beroperasi. 


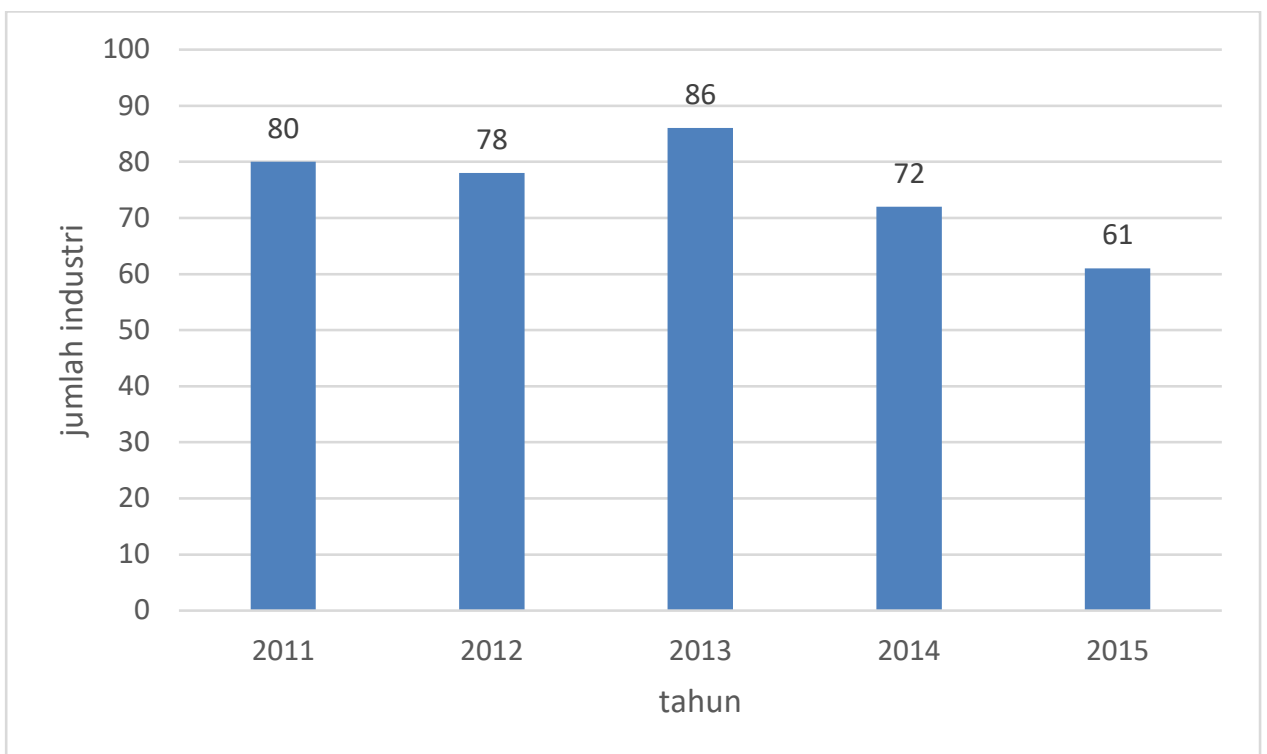

Sumber: BPS Sultra

\section{Gambar 2}

\section{Jumlah Perusahan Industri Besar dan Sedang di Provinsi Sulawesi Tenggara} Tahun 2011-2015

Gambar diatas menunjukkan jumlah perusahaan industri besar dan sedang di Sulawesi Tenggara dimana pada tahun 2011 tercatat 80 perusahaan, turun menjadi 78 perusahaan pada tahun 2012, kemudian meningkat pada tahun 2013 yang tercatat 86 perusahaan dan pada tahun 2014 turun menjadi 72 dan turun lagi di tahun 2015 hanya tercatat 61 perusahaan hal ini berdampak juga pada penurunan nilai tambah industri.

\section{Hasil Analisis Pertumbuhan Ekonomi (PDRB) Di Provinsi Sulawesi Tenggara.}

Analisis regresi pada dasarnya adalah studi ketergantungan variabel dependen (terikat) dengan satu atau lebih variabel independen (variabel penjelas atau bebas), dengan tujuan untuk mengestimasi atau memprediksi rata-rata populasi atau nilai ratarata variabel dependen berdasarkan nilai variabel independen yang diketahui (Gujarati,2007 : 37). Teknik estimasi variabel dependen yang digunakan adalah Ordinary Least Square (OLS) yaitu mengestimasi garis regresi dengan jalan meminimalkan jumlah dari kuadrat kesalahan setiap observasi terhadap garis tersebut. Pengolahan data akan dikaji menggunakan alat analisis regresi berganda. Analisis regresi linear berganda digunakan untuk menjawab rumusan masalah dengan menggunakan SPSS for windows versi 16 sehingga diperoleh persamaan dari hasil olah data sebagai berikut: 


\section{TMA JURNAL MEGA AKTIVA}

Email : megaaktiva@febi.umkendari.ac.id

Website : https://megaaktiva.umkendari.ac.id/index.php/Jurnal

\begin{tabular}{|l|l|l|l|}
\hline $\begin{array}{l}\text { Mode } \\
\perp 1\end{array}$ & $\begin{array}{c}\text { Variables } \\
\text { Entered }\end{array}$ & $\begin{array}{l}\text { Variables } \\
\text { Removed }\end{array}$ & Method \\
\hline $\begin{array}{l}\text { nilai tambah } \\
\text { industri }\end{array}$ &. & Enter \\
\hline
\end{tabular}

a. All requested variables entered.

b. Dependent Variable: PDRB

\begin{tabular}{|l|l|r|r|r|}
\multicolumn{7}{|c}{ Model Summary } \\
\hline Mode & R & R Square & $\begin{array}{c}\text { Adjusted R } \\
\text { Square }\end{array}$ & $\begin{array}{c}\text { Std. Error of } \\
\text { the Estimate }\end{array}$ \\
\hline 1 & $.656^{\sqsupset}$ & .430 & .392 & 24.00761 \\
\hline
\end{tabular}

a. Predictors: (Constant), nilai tambah industri

ANOVA ${ }^{b}$

\begin{tabular}{|ll|r|r|r|r|r|}
\hline \multicolumn{1}{|c|}{} & \multicolumn{1}{c|}{$\begin{array}{c}\text { Sum of } \\
\text { Madel }\end{array}$} & & df & Mean Square & F & Sig. \\
\hline 1 & Regression & 6533.828 & 1 & 6533.828 & 11.336 & $.004^{=}$ \\
& Residual & 8645.484 & 15 & 576.366 & & \\
& Total & 15179.312 & 16 & & & \\
\hline
\end{tabular}

a. Predictors: (Constant), nilai tambah industri

b. Dependent Variable: PDRB

Coefficients $^{3}$

\begin{tabular}{|c|c|c|c|c|c|c|}
\hline \multirow[b]{2}{*}{ Madel } & & \multicolumn{2}{|c|}{ Unstandardized Coefficients } & \multirow{2}{*}{$\begin{array}{c}\begin{array}{c}\text { Standardized } \\
\text { Coefficients }\end{array} \\
\text { Beta }\end{array}$} & \multirow[b]{2}{*}{$t$} & \multirow[b]{2}{*}{ Sig. } \\
\hline & & B & Std. Error & & & \\
\hline 1 & $\begin{array}{l}\text { (Constant) } \\
\text { nilai tambah industri }\end{array}$ & $\begin{array}{r}49.330 \\
-.061 \\
\end{array}$ & $\begin{array}{r}7.141 \\
.018 \\
\end{array}$ & -.656 & $\begin{array}{r}6.908 \\
-3.367 \\
\end{array}$ & $\begin{array}{l}.000 \\
.004\end{array}$ \\
\hline
\end{tabular}

a. Dependent Variable: PDRB

1. Uji Koefisien Determinasi $\left(\mathrm{R}^{2}\right)$

Dari hasil olah data tercatat nilai $\mathrm{R}$ Square adalah 0,430. Hal ini berarti $43 \%$ perekonomian Propinsi Sulawesi Tenggara dapat dijelaskan oleh variabel independen Nilai Tambah Industri sedangkan sisanya yaitu $57 \%$ dijelaskan oleh Faktor-faktor lain yang belum dimasukkan dalam penelitian ini.

2. Uji Signifikansi

Nilai Tambah Industri tercatat dengan tingkat signifikansi sebesar $95 \%(\alpha=5 \%)$, dengan hasil olah data $0,04<0,05$ hal menunjukkan Nilai tambah Industri berpengaruh negatif secara signifikan namun belum mampu meningkatkan PDRB di provinsi Sulawesi Tenggara.

\section{KESIMPULAN}

Berdasarkan uraian diatas maka ditemukan hasil bahwa nilai tambah Industri berpengaruh negatif terhadap PDRB di Provinsi Sulawesi Tenggara namun belum mampu meningkatkan PDRB di provinsi Sulawesi Tenggara. 


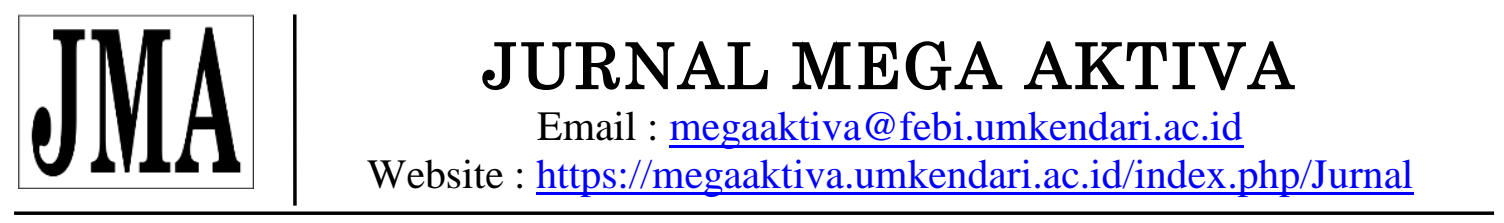

\section{DAFTAR PUSTAKA}

Apridar. 2009. Ekonomi Internasional (Sejarah, Teori, Konsep, Permasalahan Dalam Aplikasinya). Yogyakarta : Graha Ilmu.

Arikunto, Suharsimi. 2006. Prosedur Penelitian (Suatu Pendekatan Praktik). Jakarta : Rineka Cipta.

Badan Pusat Statistik. Sultra Dalam Angka. BPS Propinsi Sulawesi Tenggara.

Badan Pusat Statistik. PDRB Sulawesi Tenggara.. BPS Propinsi Sulawesi Tenggara.

Boediono. 2009. Teori Pertumbuhan ekonomi ( PDRB). Yogyakarta: BPFE YGM

Ghozali, Imam. 2009. Ekonometrika : Teori, Konsep dan Aplikasi dengan SPSS 17. Semarang : Badan Penerbit Universitas Diponegoro.

Hamdani, 2007. Seluk-beluk perdagangan Ekspor-Impor,Jakarta.

Ilham, Moch 2014. Analisis Pengaruh Kausalitas Antara Ekspor,Impor dan Pertumbuhan Ekonomi Di Indonesia Dan Thailand Dengan Menggunakan Pendekatan VAR. Jurnal Ekonomi Pembangunan Trisakti Vol.1 No. 1

Kuncoro, Mudrajad. 2007. Metode Kuantitatif Teori Dan Aplikasi Untuk Bisnis dan Ekonomi. Yogyakarta : UPP STIM YKPN.

Mahmudah, Sitti. 2011. Analisis Nilai Tambah Industri, Ekspor, Impor Dan Investasi dalam Negeri (PMDN) di DKI Jakarta. Fakultas Ekonomi dan Bisnis, UIN Syarif Hidayatullah. Jakarta

Pujiati, Amin. 2008. Analisis Pertumbuhan ekonomi ( PDRB) di Karesidenan Semarang Era Desentralisasi Fiskal. Jurnal Ekonomi Pembangunan Vol. 13 No. 2.

Sugiyono. 2007. Statistika Untuk Penelitian. Bandung : CV ALFABETA.

Widarjono, Agus. 2009. EkonJmetrika pengantar dan aplikasinya. Yogyakarta : Ekonisia.

Widodo, Tri. 2006. Perencanaan Pembangunan: Aplikasi Komputer (Era Otonomi Daerah).Yogyakarta: UPP STIM 